\title{
Corrosion of High Carbon Steel by Bacteria under Aerobic and Anaerobic Conditions
}

\author{
R. C. Nwokorie ${ }^{1}$, C. O. Nweke ${ }^{1}$, S. I. Umeh ${ }^{1}$, F. C. Ihenetu ${ }^{1 *}$, O. R. Nlemolisa ${ }^{1}$, U. N. Kemka1, \\ C. C. Obasi², C. I. Nnadi ${ }^{3}$, K. H. Uzoho' ${ }^{1}$, C. C. Ejide ${ }^{1}$ \\ ${ }^{1}$ Department of Microbiology, Federal University of Technology, Owerri, Nigeria \\ ${ }^{2}$ Department of Public Health, Imo State University, Owerri, Nigeria \\ ${ }^{3}$ Department of Pathology, Imo State University Teaching Hospital, Orlu, Nigeria \\ Email: *ihenetufrancis@gmail.com
}

How to cite this paper: Nwokorie, R.C. Nweke, C.O., Umeh, S.I., Ihenetu, F.C., Nlemolisa, O.R., Kemka, U.N., Obasi, C.C., Nnadi, C.I., Uzoho, K.H. and Ejide, C.C. (2019) Corrosion of High Carbon Steel by Bacteria under Aerobic and Anaerobic Conditions. Materials Sciences and Applications, 10, 227-242.

https://doi.org/10.4236/msa.2019.103019

Received: January 11, 2019

Accepted: March 22, 2019

Published: March 25, 2019

Copyright (c) 2019 by author(s) and Scientific Research Publishing Inc. This work is licensed under the Creative Commons Attribution International License (CC BY 4.0).

http://creativecommons.org/licenses/by/4.0/

\begin{abstract}
The role of microbes in the corrosion of metals is due to the chemical activities (metabolism) associated with the microbial growth and reproduction. A lot of researches have shown that enormous loss of resources and even lives has been experienced in many countries of the world due to corrosion. There is therefore need to device a means of combating this menace so as to save different countries of the world including Nigeria the cost encured due to corrosion. This research has helped to determine the role of bacteria in the corrosion of high carbon steel under aerobic and anaerobic conditions was investigated using sulphate reducing bacteria and other aerobes. A sample of high carbon steel grade of chemical composition: $96 \%$ iron $(\mathrm{Fe}), 1.08 \%$ carbon $(\mathrm{C}), 0.349 \%$ silicon $(\mathrm{Si}), 0.841 \%$ manganese $(\mathrm{Mn}), 0.005 \%$ phosphorus (P) and $0.005 \%$ sulphur (S), was obtained in the form of steel plate. Eighteen (18) samples of the high carbon steel were prepared. Standard microbiological methods were used to isolate aerobic and anaerobic bacteria isolates. The microbes isolated from the soil included; aerobes (Bacillus species, Pseudomonas species) and anaerobes (Desulfovibrio species, Thiobacillus species). The role of bacteria in the corrosion of high carbon steel was estimated using the weight loss technique and the electrochemical potential measurement technique. Eighteen samples of a high carbon steel of known compositions were exposed to sulphate reducing bacteria under different environments (aerobic, anaerobic and control). The physical and chemical changes were examined and monitored on weekly basis for six weeks. It was observed that the coupons immersed in the media with sulphate reducing bacterium underwent fast activation and numerous corrosion sites were formed on the surfaces. The average corrosion rate for six weeks ( 42 days) period of time as determined by the weight loss method and electrochemical testing were
\end{abstract}


found to be $0.0004595 \mathrm{~mm} /$ year, $-0.712 \mathrm{mV}$ in aerobic environment, $0.0005646 \mathrm{~mm} /$ year, $-0728 \mathrm{mV}$ in anaerobic environment and 0.0004458 $\mathrm{mm}$ /year, $-0702 \mathrm{mV}$ in the control or reference environment (distilled water environment). High carbon steel was found to corrode more only in the anaerobic environment. In view of this, high carbon steels were found to be relatively more corrosion resistant than mild and medium carbon steels and may be suitable for application in industries such as the petrochemical industry. Therefore, treating the environment with chlorine but with caution as solutions of chlorine gas in water is corrosive to steels while the use of bactericides or biocides to arrest the action of microbes is important.

\section{Keywords}

Bacillus Species, Pseudomonas Species, Desulfovibrio Species, Thiobacillus Species, Corrosion, Steel

\section{Introduction}

Corrosion may be defined as the deterioration of a material resulting from chemical attack by its environment [1]. Metals actually corrode because they succumb to environmental interaction. The environment in this regard may refer to the service conditions where the metal may find application. Steel, due to their desirable mechanical properties, in practice find application in many service conditions including the aquatic environment where the activity of microbes such as bacteria is evident. The role of microbes in the corrosion of metals is due to the chemical activities (metabolism) associated with the microbial growth and reproduction [1]. In the metabolic and growth process, bacteria can reproduce up to $2.8 \times 10^{14}$ organisms every $10-60$ minutes, which is responsible for the corrosion and biodeterioration of materials exposed to such environment [2]. Microbial influenced corrosion (MIC) is due to the presence and activities of microorganisms including bacteria and fungi, and affects a wide range of industries resulting in severe economic loss [3]. Carbon steel, although susceptible to corrosion, is frequently employed in industries and infrastructure because of its strength, availability, relatively low cost and fire resistance [4]. Infrastructure affected by MIC (buried pipelines) is often operated under anaerobic or micro aerobic conditions [5]. Most studies on anaerobic-micro aerobic MIC use sulphate reducing bacteria (SRBs) because they are sulphide producers and promoters of the cathodic depolarization process in steel [6] [7]. According to von Wolzogen and Van der Vlugt [8], under anaerobic conditions, electrons from the metal surface (cathode) reduce protons to form hydrogen, which form film that prevents further proton reduction, thus producing electrostatic isolation (passivation). Different bacteria that colonized the metal surface can consume the hydrogen film, resulting in $\mathrm{Fe}^{2+}$ release from the metal surface. Sulphide produced by SRBs combines with and $\mathrm{Fe}^{2+}$ to form ferrous sulphide and generate 
an adhesion film. This mineral film acts as a cathode for hydrogen evolution, thus increasing the corrosion rate [9], but can also have a protective passivation effect depending on the crystalline mineral composition [9] [10]. The differences in SRBs-related corrosive effect are also caused at least in part, by the SRB species themselves [10], in addition to other factors. A natural environment, the reaction leading to steel corrosion intensify with temperature [11], and high-temperature environment is characterized by diverse bacteria communities [12], many of which may have corrosive effect [13] [14].

Desulfovibrio spp. are members of sulphate reducers, which are found to exist in all soil and water types, as well as lives symbiotically with facultative anaerobic bacteria [15]. Sulphate-reducing bacteria (SRB) are a group of anaerobic diverse organisms which have varied morphological and nutritional characteristics. They utilize organic matter to produce sulphide by either reducing or oxidizing sulphate compounds [16], as a source of energy. Therefore, sulphate $\left(\mathrm{SO}_{4}^{2-}\right)$ can be reduced to sulphide $\left(\mathrm{S}^{2-}\right)$ by SRB leading to the generation of hydrogen sulphide as a metabolic by-product. Both physical and chemical processes transfer hydrogen sulphide $\left(\mathrm{H}_{2} \mathrm{~S}\right)$ across the air and water boundaries to environment where chemoautotrophic bacteria oxidize the sulphide to sulphuric acid [17]. The corrosion process will hence occur by the reaction of the biogenic sulphuric acid with the metallic surfaces [12].

In order to evaluate the significance of microbial corrosions, a look at the economical perspective of such effects is essential. In 2001, the cost of microbial-influenced corrosion on oil and gas industries accounted for about two billion dollars annually in the United States of America [4]. This study is therefore aimed at determining the corrosion of high carbon steel by bacteria under aerobic and anaerobic environments.

\section{Methodology}

\subsection{Sample Collection}

A sample of high carbon steel grade of chemical composition: $96 \%$ iron $(\mathrm{Fe})$, $1.08 \%$ carbon $(\mathrm{C}), 0.349 \%$ silicon $(\mathrm{Si}), 0.841 \%$ manganese $(\mathrm{Mn}), 0.005 \%$ phosphorus $(\mathrm{P})$ and $0.005 \%$ sulphur $(\mathrm{S})$, was obtained in the form of steel plate. The chemical analysis of the sample was done using the spectroscopy method at Testing Research and Certification Engineering Services, Port Harcourt, Nigeria in accordance with American Society for Testing Materials [18].

\subsection{Sample Preparation}

The high carbon steel plate was cut to a dimension of $28 \times 28 \times 2 \mathrm{~mm}$ using hack saw blade according to the standard of American Society for Testing Materials [18]. The size and shape (flat surface) were chosen for ease of measurement and convenience. Eighteen (18) samples of the high carbon steel were prepared.

\subsection{Treatment of the Environment}

Twenty samples of soil were collected from different locations in Ebeocha in 
Rivers State and Orji mechanic village in Owerri, Imo State for the isolation of the microorganisms. The soil samples were collected at a depth of $2 \mathrm{~cm}$ as described under National Association of Corrosion Engineers [19] standard. Small portion of the soil was polluted with $20 \mathrm{~g}$ of sulphur powder and allowed for the period of two weeks. The soil sample was collected and $1 \mathrm{~g}$ of the polluted soil was suspended in $9 \mathrm{ml}$ of sterile distilled water. This constituted the $10^{-1}$ dilution. The test tube was shaken and a sterile $10 \mathrm{ml}$ pipette was used to transfer $1 \mathrm{ml}$ of the $10^{-1}$ dilution into a test tube containing $9 \mathrm{ml}$ sterile distilled water to achieve the $10^{-2}$ dilution. The content of $10^{-2}$ dilution was shaken and the dilution continued (always using a fresh sterile pipette for each transfer) until the $10^{-6}$ dilution was obtained according to American Public Health Association [20] standard. After the serial dilution was completed, an aliquot $(0.1 \mathrm{ml})$ of the $10^{-2}$ dilution was inoculated onto a mineral salt agar plates using spread plate technique and allowed for 24 hours at $32^{\circ} \mathrm{C}$. The mineral salts agar composed of $10 \mathrm{~g}$ of $\mathrm{NaCl}, 0.42 \mathrm{~g}$ of $\mathrm{MgSO}_{4} .7 \mathrm{H}_{2} \mathrm{O}, 0.29 \mathrm{~g}$ of $\mathrm{KCl}, 0.83 \mathrm{~g}$ of $\mathrm{K}_{2} \mathrm{H}_{2} \mathrm{PO}_{4}, 0.42 \mathrm{~g}$ of $\mathrm{NaNO}_{3}$ and $12.5 \mathrm{~g}$ of agar per litre. Some of the organisms isolated from the soil samples after the inoculation on a mineral salt agar were aerobes which include Bacillus spp., Pseudomonas spp. An aliquot $0.1 \mathrm{ml}$ of the $10^{-2}$ dilution was inoculated unto a nutrient-rich Baar's medium using spread plate technique and allowed for 24 hours at $32^{\circ} \mathrm{C}$. The medium consisted of sodium lactate $(6.0 \mathrm{~g} / \mathrm{l})$, sodium sulphate $(4.5 \mathrm{~g} / \mathrm{l})$, ammonium chloride $(1.0 \mathrm{~g} / \mathrm{l})$, yeast extract $(1.0 \mathrm{~g} / \mathrm{l})$, potassium phosphate $(0.5 \mathrm{~g} / \mathrm{l})$, sodium citrate $(0.3 \mathrm{~g} / \mathrm{l})$, calcium chloride $(0.06$ $\mathrm{g} / \mathrm{l})$, magnesium sulphate $(0.06 \mathrm{~g} / \mathrm{l})$ and iron sulphate $(0.004 \mathrm{~g} / \mathrm{l})$. The bacterial strains obtained from the above exercise were then tested using an SRB kit and an iron reducing bacteria kit. The anaerobes isolated include Desulfovibrio spp. And Thiobacillus spp. The isolates were purified and sulphate reducing bacteria were inoculated onto the Baar's medium in the anaerobic container. Bacillus species was inoculated onto the mineral salt medium in the aerobic container. SRB growth was observed as strong black precipitate formation on the medium due to intensive FeS production. The $\mathrm{pH}$ and concentration of the growth medium in each environment was measured and recorded.

\subsection{Corrosion Measurement}

The steel coupons (samples) were cleaned and dried before exposure to their respective environment. The initial weight and dimensions of the specimens were measured and recorded. The samples were then suspended with the aid of a rubber thread which passed through the drilled hole in each sample into the environment (aerobic and anaerobic), with respect to the control environment (distilled water) as described by Oparaodu and Okpokwasili [21].

\subsection{Visual Inspection}

Visual examination carried out revealed the presence of corrosion products and oxide scales somewhat brownish in colour on the surface of the sample. The 
corrosion products such as the oxide films were scraped out, ground and mixed with few drops of sodium hydroxide solution $\left(\mathrm{NaOH}_{\mathrm{aq}}\right)$ in a test tube.

\subsection{The Weight Loss Technique}

The bacterial corrosion of the high carbon steel in aerobic and anaerobic environments with respect to a distilled water-control environment was studied and evaluated by the weight loss of the samples at periodic intervals of one week. A weighing balance Mettle Toledo (New classic ML 204 Switzerland) was used to determine the weight loss of the steel coupon. The initial weight of the samples before introducing them into the different environments were determined and recorded. The weight of the samples, that is the final weight after corrosion must have taken place were also determined and recorded. The loss in weight after each exposure time was calculated from the equation below:

$$
W_{1}=W_{o}-W_{i}
$$

where $W_{1}=$ weight loss $(\mathrm{g}), W_{o}=$ initial weight $(\mathrm{g})$ before each exposure time $(\mathrm{T}$ days) and $W_{i}=$ final weight in grams after each exposure time ( $\mathrm{T}$ days).

$$
\text { Percentage weight loss }=\frac{W_{o}-W_{i}}{W_{o}} \times 100
$$

\subsection{Electrical Potential Measurement Method}

This method as described by ASTM, [18] standard indicates if the metal specimen is passive (non-corroding) or active (corroding). The method is simple, only needing an appropriate electrode (copper electrode with copper sulphate electrolyte) and voltage measuring instrument [22]. An electrical potential measurement was conducted using a copper electrode as a reference electrode and high carbon steel as the working electrode in a standard electrochemical glass cell with copper sulphate as the electrolyte. The test were operated using the PARSTAT 2273 electrochemical measurement system manufactured by EG\&G. The instrument was used to read the electrochemical potential values of the steel coupons before and after the exposure time.

\section{Results}

The results of the weight loss and corrosion rate of the steel coupons in aerobic, anaerobic and distilled water (control) environments are shown in Tables 1-3. Figures 1-3 show the plots of weight loss versus exposure time in the different environment. The lowest weight loss of $0.0201 \mathrm{~g}$ in aerobic, $0.0247 \mathrm{~g}$ in anaerobic and $0.0195 \mathrm{~g}$ in distilled water environment were observed in day 7. The highest weight loss $0.0714 \mathrm{~g}$ in aerobic, $0.0939 \mathrm{~g}$ in anaerobic and $0.0669 \mathrm{~g}$ in distilled water environments were observed in day 28.

Figures 4-6 show the plots of the corrosion rate versus exposure time in the different environment. The lowest corrosion rate of $0.0002667 \mathrm{~mm} / \mathrm{yr}$ in aerobic, $0.0003067 \mathrm{~mm} / \mathrm{yr}$ in anaerobic and $0.0002290 \mathrm{~mm} / \mathrm{yr}$ in distilled water environment were observed on day 42 . The highest corrosion rate of $0.0004595 \mathrm{~mm} / \mathrm{yr}$ 
Table 1. Weight losses and corrosion rates of steel coupons in aerobic environment.

\begin{tabular}{cccccc}
\hline $\begin{array}{c}\text { Exposure } \\
\text { Time }(\mathrm{T}) \text { day }\end{array}$ & $\begin{array}{c}\text { Initial weight } \\
\left(W_{o}\right) \mathrm{g}\end{array}$ & $\begin{array}{c}\text { Final weight } \\
\left(W_{i}\right) \mathrm{g}\end{array}$ & $\begin{array}{c}\text { Weight loss } \\
\left(W_{1}\right) \mathrm{g}\end{array}$ & $\begin{array}{c}\text { Corrosion rate } \\
(\mathrm{CR}) \mathrm{mm} / \mathrm{yr} .\end{array}$ & $\begin{array}{c}\text { \% Weight } \\
\text { loss }\end{array}$ \\
\hline 0 & - & - & - & - & - \\
7 & 9.9378 & 9.9177 & 0.0201 & 0.0004595 & 0.2022 \\
14 & 11.7102 & 11.6745 & 0.0357 & 0.0004080 & 0.3048 \\
21 & 14.8781 & 14.8258 & 0.0523 & 0.0003985 & 0.3515 \\
28 & 9.9467 & 9.8753 & 0.0714 & 0.0004080 & 0.7178 \\
35 & 15.3923 & 15.3221 & 0.0702 & 0.0003209 & 0.4560 \\
42 & 13.0048 & 12.9348 & 0.0700 & 0.0002667 & 0.5382 \\
\hline
\end{tabular}

Table 2. Weight losses and corrosion rates of steel coupons in anaerobic environment.

\begin{tabular}{cccccc}
\hline $\begin{array}{c}\text { Exposure } \\
\text { Time }(\mathrm{T}) \text { day }\end{array}$ & $\begin{array}{c}\text { Initial weight } \\
\left(W_{o}\right) \mathrm{g}\end{array}$ & $\begin{array}{c}\text { Final weight } \\
\left(W_{i}\right) \mathrm{g}\end{array}$ & $\begin{array}{c}\text { Weight loss } \\
\left(W_{1}\right) \mathrm{g}\end{array}$ & $\begin{array}{c}\text { Corrosion rate } \\
(\mathrm{C} . \mathrm{R}) \mathrm{mm} / \mathrm{yr} .\end{array}$ & $\begin{array}{c}\text { \% Weight } \\
\text { loss }\end{array}$ \\
\hline 0 & - & - & - & - & - \\
7 & 11.0777 & 11.0530 & 0.0247 & 0.0005646 & 0.2229 \\
14 & 11.9859 & 11.9448 & 0.0411 & 0.0004698 & 0.3429 \\
21 & 9.2557 & 9.1932 & 0.0625 & 0.0004762 & 0.6752 \\
28 & 11.0338 & 10.9399 & 0.0939 & 0.0005366 & 0.8510 \\
35 & 9.0682 & 8.9853 & 0.0830 & 0.0003795 & 0.9152 \\
42 & 11.8944 & 11.8139 & 0.0805 & 0.0003067 & 0.6767 \\
\hline
\end{tabular}

Table 3. Weight losses and corrosion rates of steel coupons in control environment (distilled water).

\begin{tabular}{cccccc}
\hline $\begin{array}{c}\text { Exposure } \\
\text { Time (T) day }\end{array}$ & $\begin{array}{c}\text { Initial weight } \\
\left(W_{o}\right) \mathrm{g}\end{array}$ & $\begin{array}{c}\text { Final weight } \\
\left(W_{i}\right) \mathrm{g}\end{array}$ & $\begin{array}{c}\text { Weight loss } \\
\left(W_{1}\right) \mathrm{g}\end{array}$ & $\begin{array}{c}\text { Corrosion rate } \\
(\mathrm{CR}) \mathrm{mm} / \mathrm{yr} .\end{array}$ & $\begin{array}{c}\text { \% Weight } \\
\text { loss }\end{array}$ \\
\hline 0 & - & - & - & - & - \\
7 & 16.4389 & 16.4194 & 0.0195 & 0.0004458 & 0.1186 \\
14 & 11.5512 & 11.5295 & 0.0217 & 0.0002480 & 0.1878 \\
21 & 12.5035 & 12.4633 & 0.0402 & 0.0003063 & 0.3215 \\
28 & 14.9969 & 14.9300 & 0.0669 & 0.0003823 & 0.4460 \\
35 & 10.7760 & 10.7135 & 0.0625 & 0.0002857 & 0.5799 \\
42 & 9.0040 & 8.9439 & 0.0601 & 0.0002290 & 0.6674 \\
\hline
\end{tabular}

in aerobic, $0.0005646 \mathrm{~mm} / \mathrm{yr}$ in anaerobic and $0.0004458 \mathrm{~mm} / \mathrm{yr}$ in distilled water environments were observed in day 7.

Tables 4-6 show the results of the electrode potentials of the samples and concentrations of the medium in different environments.

Figures 7-9 show the plots of electrode potentials versus exposure time in the different environments. The lowest electrode potentials of $-0.712 \mathrm{mV}$ in aerobic and $-0.717 \mathrm{mV}$ in anaerobic were observed on day 35 and $-0.072 \mathrm{mV}$ in distilled water was observed on day 28 . The highest electrode potential of $-0.550 \mathrm{mV}$ 


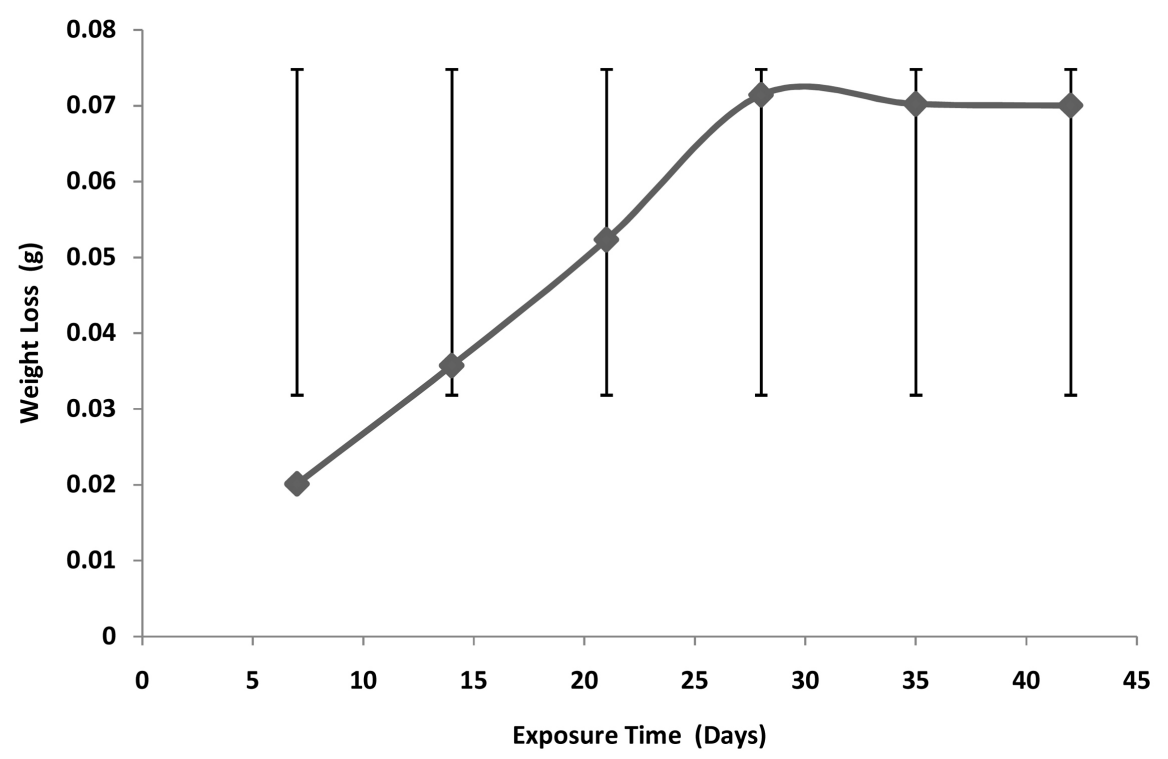

Figure 1. Weight loss (grams) against the exposure time (days) in the aerobic environment.

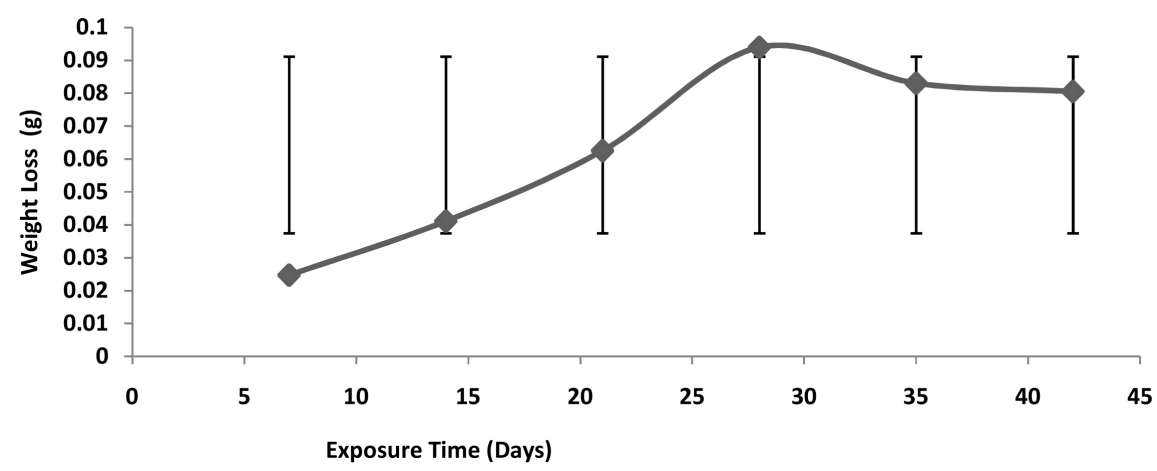

Figure 2. Weight loss (grams) against the exposure time (days) in the anaerobic environment.

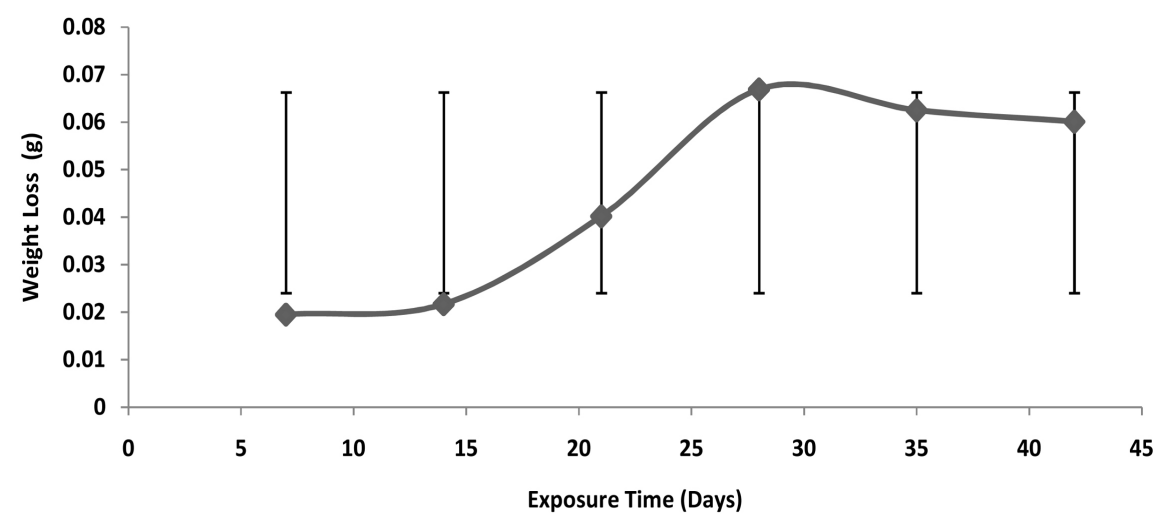

Figure 3. Weight loss (grams) against the exposure time (days) in the control environment.

in aerobic, $-0.554 \mathrm{mV}$ in anaerobic and $-0.550 \mathrm{mV}$ in distilled water environment were observed on day zero. 


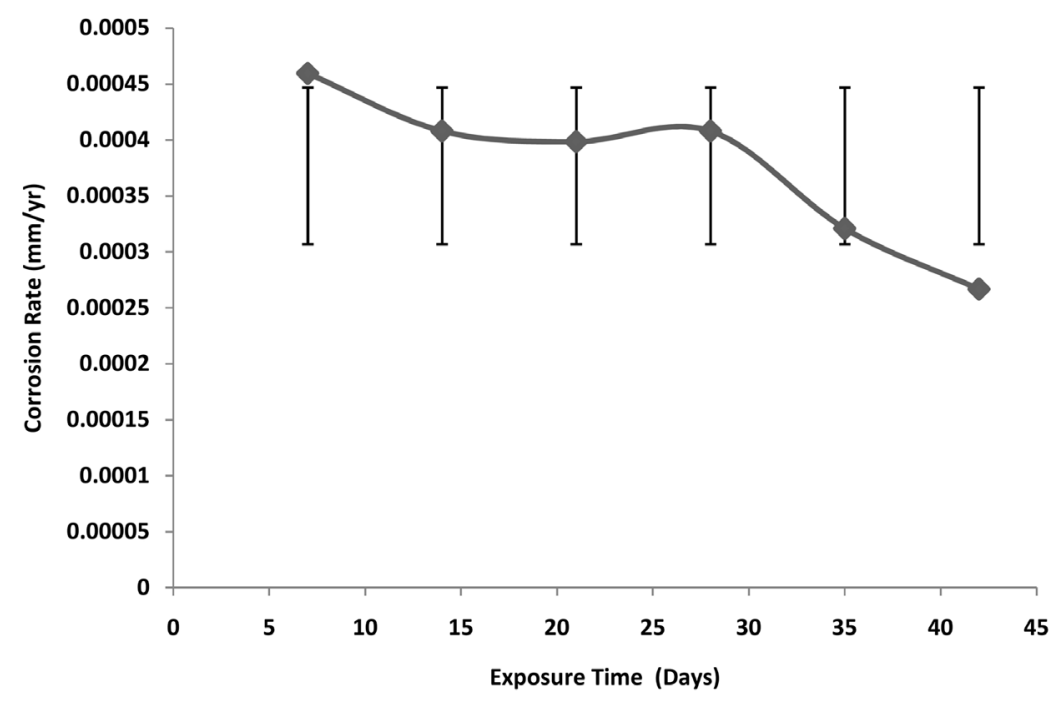

Figure 4. Corrosion rate $(\mathrm{mm} / \mathrm{yr})$ against the exposure time (days) in the aerobic environment.

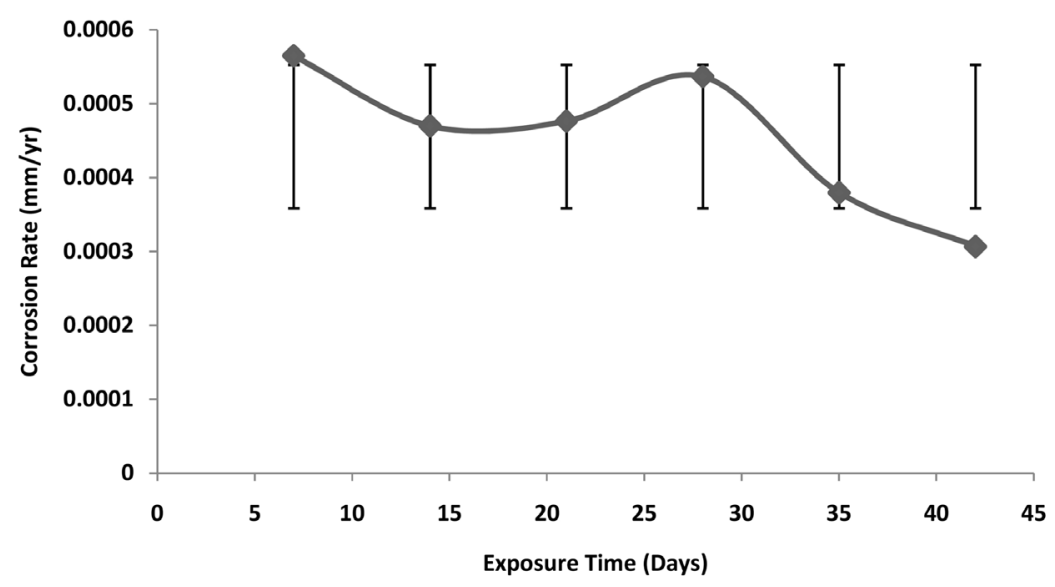

Figure 5. Corrosion rate $(\mathrm{mm} / \mathrm{yr})$ against the exposure time (days) in the anaerobic environment.

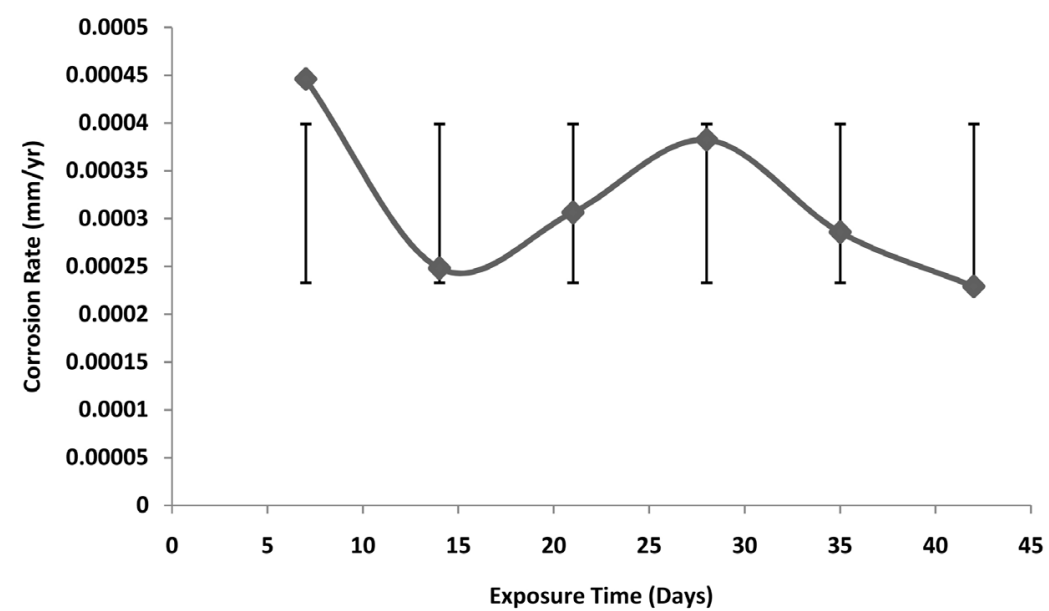

Figure 6. Corrosion rate $(\mathrm{mm} / \mathrm{yr})$ against the exposure time (days) in the control environment. 


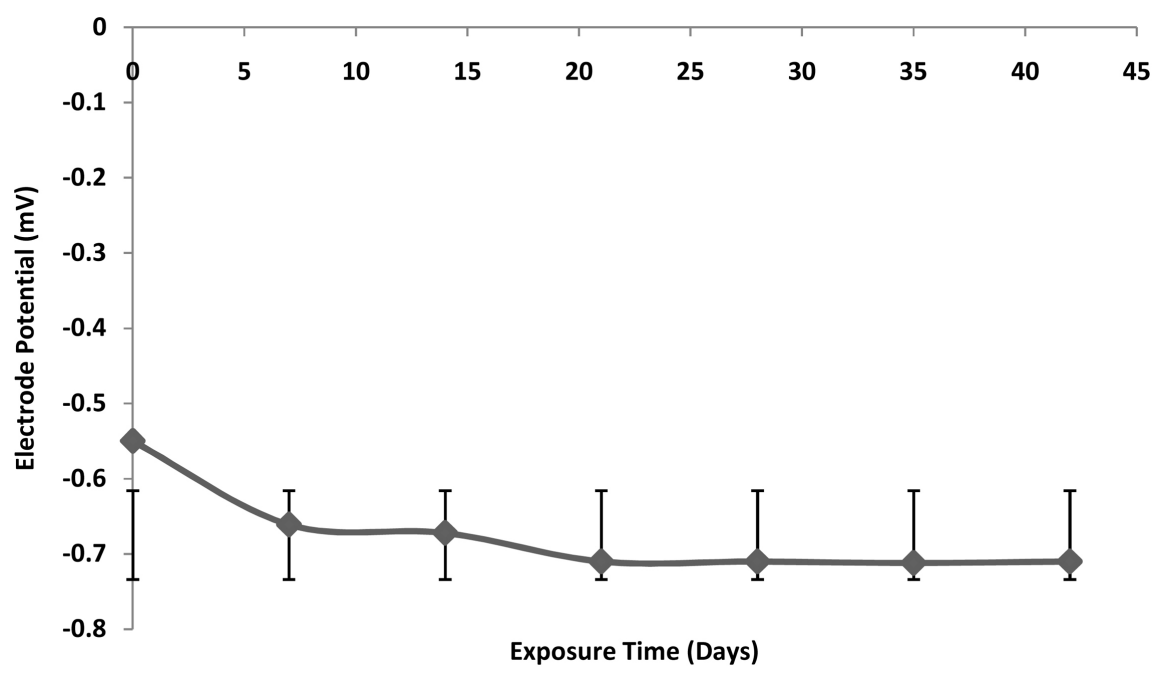

Figure 7. Electrode potential (millivolt) against exposure time (days) in aerobic environment.

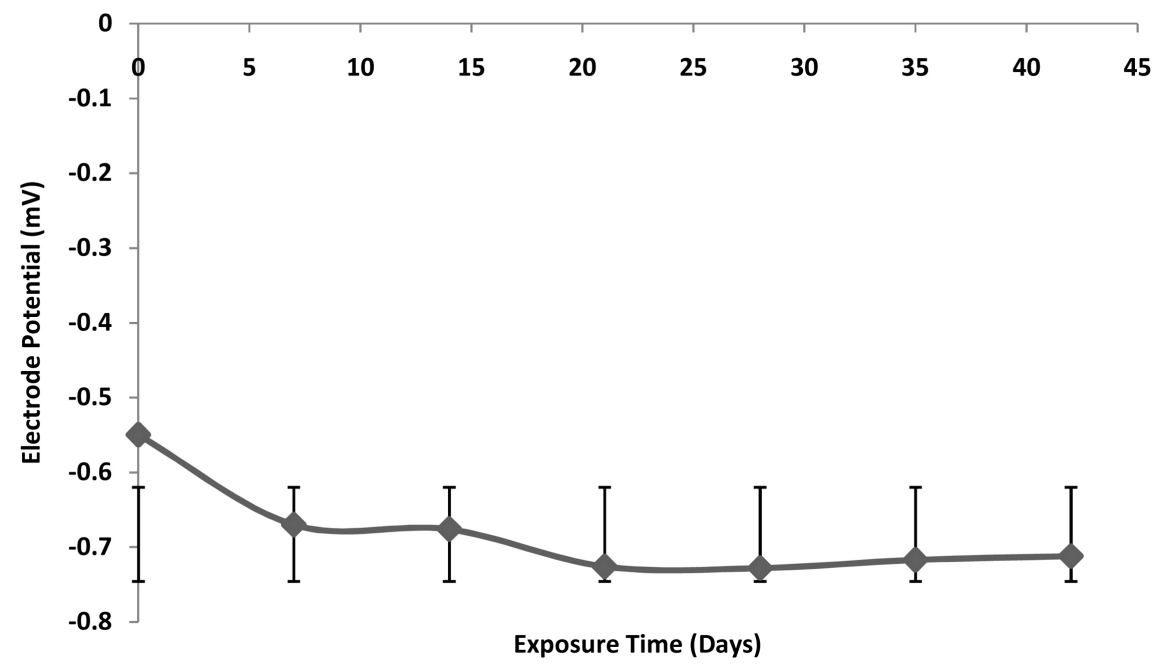

Figure 8. Electrode potential (millivolts) against exposure time (days) in anaerobic environment.

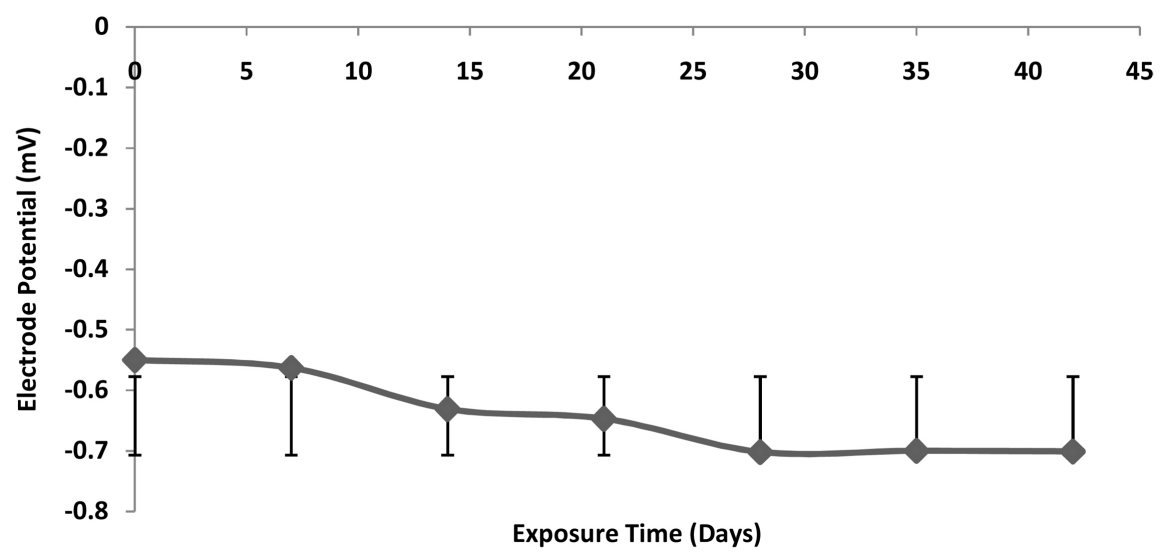

Figure 9. Electrode potential (millivolts) against exposure time (days) in control environment. 
Table 4. Electrode potential and concentration in aerobic environment.

\begin{tabular}{cccc}
\hline $\begin{array}{c}\text { Exposure Time } \\
(\text { days })\end{array}$ & $\begin{array}{c}\text { Electrode Potential } \\
(\mathrm{mV})\end{array}$ & $\begin{array}{c}\mathrm{pH} \text { of } \\
\text { Environment }\end{array}$ & $\begin{array}{c}\text { Concentration of mineral } \\
\text { salt medium in mil/litre }\end{array}$ \\
\hline 0 & -0.550 & 7.0 & 500 \\
7 & -0.661 & 6.8 & 510 \\
14 & -0.672 & 5.0 & 520 \\
21 & -0.710 & 5.0 & 525 \\
28 & -0.710 & 5.0 & 530 \\
35 & -0.712 & 4.0 & 530 \\
42 & -0.710 & 6.0 & 535 \\
\hline
\end{tabular}

Table 5. Electrode potential and concentration in anaerobic environment.

\begin{tabular}{cccc}
\hline $\begin{array}{c}\text { Exposure Time } \\
(\text { days })\end{array}$ & $\begin{array}{c}\text { Electrode Potential } \\
(\mathrm{mV})\end{array}$ & $\begin{array}{c}\mathrm{pH} \text { of } \\
\text { Environment }\end{array}$ & $\begin{array}{c}\text { Concentration of the Baar's } \\
\text { medium in mil/litre }\end{array}$ \\
\hline 0 & -0.554 & 7.0 & 500 \\
7 & -0.670 & 6.8 & 512 \\
14 & -0.676 & 6.0 & 524 \\
21 & -0.726 & 5.0 & 536 \\
28 & -0.728 & 5.0 & 548 \\
35 & -0.717 & 4.0 & 548 \\
42 & -0.712 & 6.0 & 560 \\
\hline
\end{tabular}

Table 6. Electrode potential and concentration in control environment.

\begin{tabular}{cccc}
\hline $\begin{array}{c}\text { Exposure Time } \\
\text { (days) }\end{array}$ & $\begin{array}{c}\text { Electrode Potential } \\
(\mathrm{mV})\end{array}$ & $\begin{array}{c}\mathrm{pH} \text { of } \\
\text { Environment }\end{array}$ & $\begin{array}{c}\text { Concentration of the } \\
\text { distilled water in mil/litre }\end{array}$ \\
\hline 0 & -0.550 & 7.0 & 500 \\
7 & -0.563 & 6.8 & 505 \\
14 & -0.631 & 6.8 & 510 \\
21 & -0.647 & 6.8 & 515 \\
28 & -0.702 & 6.8 & 520 \\
35 & -0.700 & 6.8 & 520 \\
42 & -0.701 & 7.0 & 525 \\
\hline
\end{tabular}

Figures 10-12 show the plots of the concentration of the media versus the exposure time in different environments. The lowest concentrations of $500 \mathrm{ml} / \mathrm{l}$ was observed on day zero for all the environments. The highest concentrations of $535 \mathrm{ml} / \mathrm{l}$ in aerobic, $560 \mathrm{ml} / \mathrm{l}$ in anaerobic and $525 \mathrm{ml} / \mathrm{l}$ in distilled water environment were observed on day 42 .

Average initial electrode potential value of the specimen $=-0.553 \mathrm{mV}$.

Initial $\mathrm{pH}$ reading of the aerobic, anaerobic and control environments are 7.0, 7.0 and 7.0 respectively.

Initial concentration of the aerobic, anaerobic and control environment are 


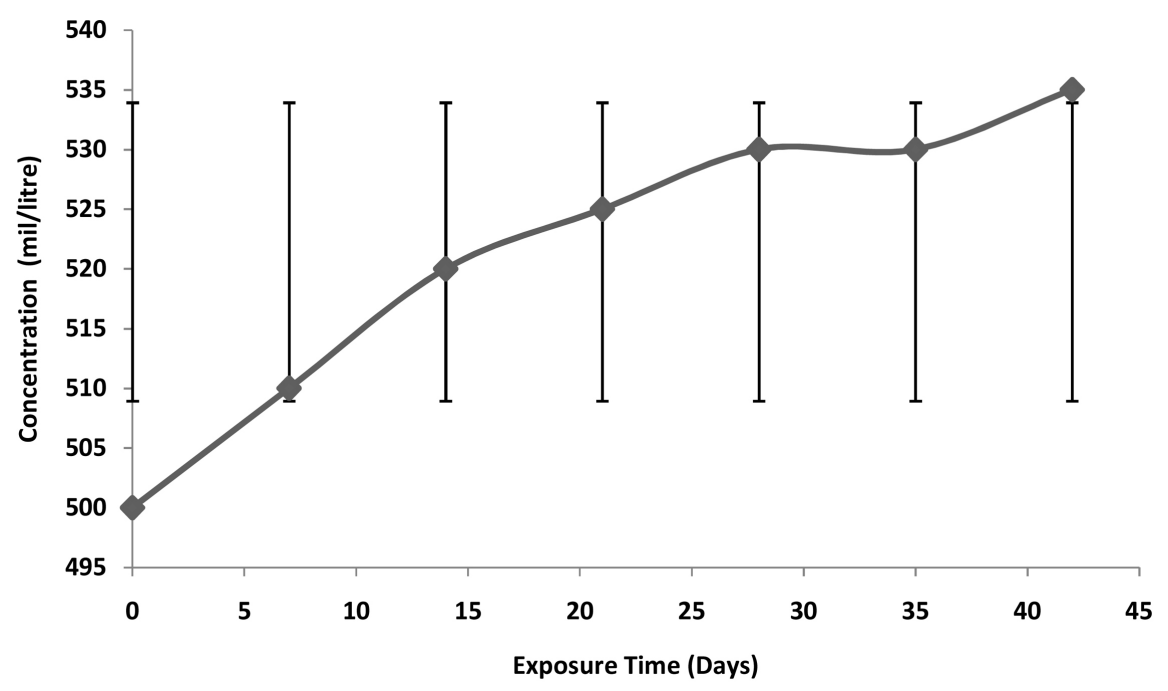

Figure 10. Concentration (ml/l) against exposure time (days) in aerobic environment.

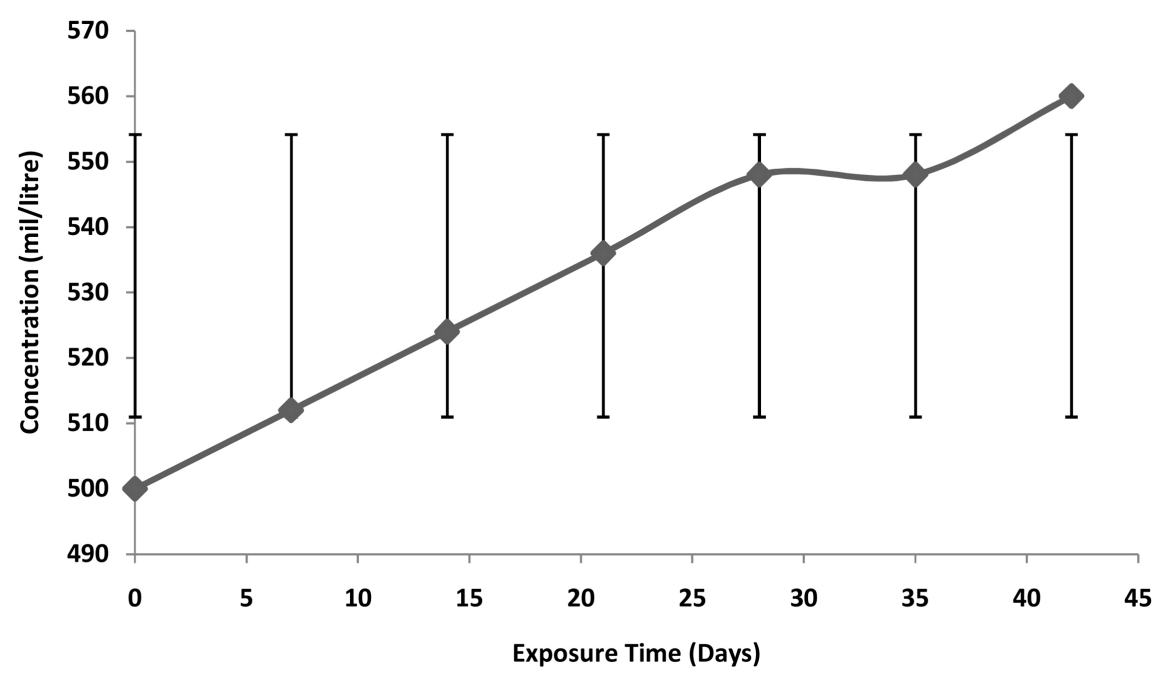

Figure 11. Concentration (ml/l) against exposure time (days) in anaerobic environment.

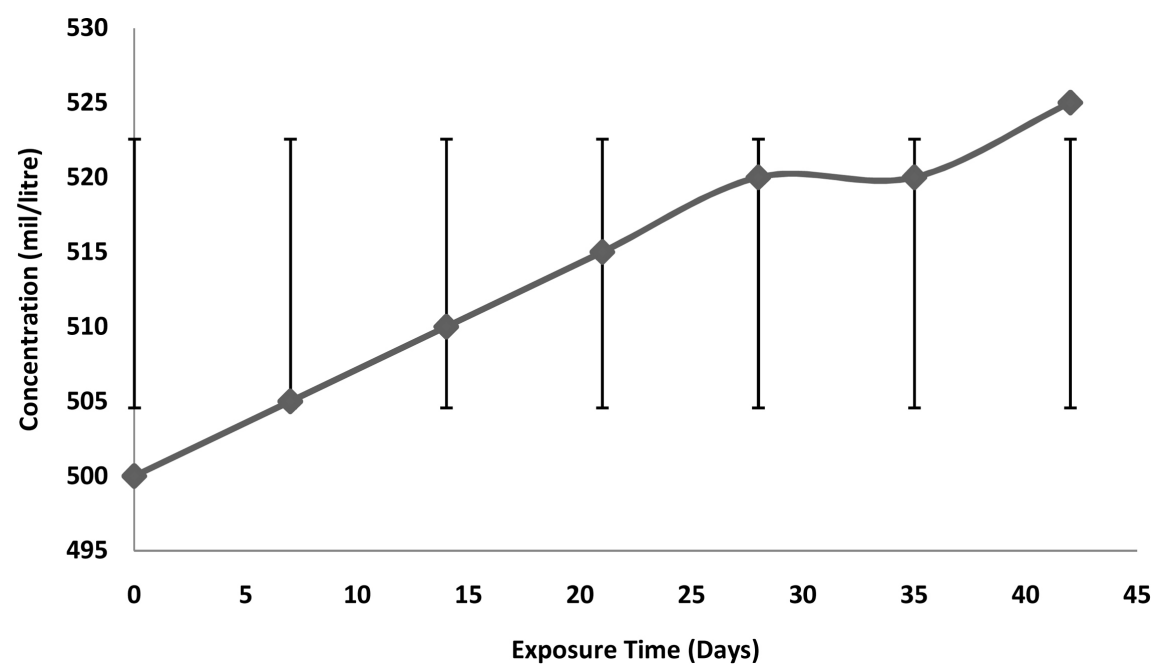

Figure 12. Concentration (ml/l) against exposure time (days) in control environment. 
$500 \mathrm{~m} /$ litre, $500 \mathrm{~m} /$ litre and $500 \mathrm{~m} /$ litre respectively.

\section{Discussion}

In this study, the high carbon steel appeared to corrode faster in anaerobic environment than in aerobic environment. The corrosion rate was observed to be highest in the first 7 days $(0.0005646 \mathrm{~mm} / \mathrm{yr})$ and then decreased with exposure time in each environment. The formation of a passive oxide film on the surface of the specimen is believed to be responsible for the observation. Moreover, by observing the pattern of corrosion rate in the entire three environments, it is apparent that the highest corrosion rate was measured in the first seven days before the rate started to decrease. These reflect the power law pattern of corrosion growth. This is in agreement with Yuzwa et al. [23] work on sulphate reducing bacteria corrosion. The formation of rust and the depletion of food supply in a medium has restricted the progress of corrosion, hence the decrease in metal loss volume. The corrosion rate tends to be higher in anaerobic environment. This is in agreement with Carpen et al. [24] who demonstrated that corrosion rate might be as high as $10-63$ micrometer per annum in anaerobic environment. Such high corrosion rate in anoxic ground water cannot occur without the acceleration of the corrosion process by microbial activities [24].

Owate [25] reported that the corrosion rates obtained for mild steel supported the fact that carbon content in itself has little effect if any on the general corrosion resistance of the steel. Ovri [26] found that mild steel corroded more than medium carbon steel in the aerobic as well as in the anaerobic environment.

The corrosion inducing agents predominant in the environment were $\mathrm{OH}^{-}$ and $\mathrm{SO}_{4}^{2-}$ radicals according to Ovri [26].

$$
4 \mathrm{Fe}(\mathrm{s})+\mathrm{SO}_{4}^{2-}(\mathrm{aq})+4 \mathrm{H}_{2} \mathrm{O} \rightarrow \mathrm{FeS}(\mathrm{s})+3 \mathrm{Fe}(\mathrm{OH})_{2}+2 \mathrm{OH}^{-}
$$

The electrode potential decreased as resistance increases due to corrosion products formed on the steel surface. The corrosion product formed with the exposure time raises the resistance of the sample thereby decreasing the electrode potential values. The result obtained on weekly basis showed that the electrode potential value of the exposed samples decreases with exposure time to a certain extent corresponding to 28 days. This is believed to be due to formation of corrosion products which leads to resistance polarization of the samples [22].

This implies that the electrode potential values decrease with exposure time. This result is in agreement with the findings of Jin et al. [15] and also confirmed the result of weight loss measurement. Weight loss was found to increase with time and concentration. Ovri, et al. [26] in their work on microbial corrosion of mild and medium carbon steel observed that the bacteria concentration of the environment increases with the time of exposure in days. The result of the weight of the respective specimen after each exposure time was taken and recorded. In addition, weight loss increased as $\mathrm{pH}$ is decreased, making the environment more acidic and consequently more corrosive. This study agrees with the findings of Oparaodu et al. [21] who reported that generally the weight loss 
of the steel increased with the exposure time whereas the corrosion rate decreased with the exposure time. This also agrees with the report of Wan et al. [27] on corrosion rate. The result equally showed a general pattern of increase in percentage weight loss and a corresponding decrease in corrosion rate with respect to time.

Initially corrosion in the anaerobic environment was severe, this can be explained from the fact that when oxygen is not available for the removal of electrons from the metal surface, an alternative cathode reaction is necessary for corrosion to occur. This suggested that sulphate-reducing bacteria contribute directly to the corrosion of iron by the removal and utilization of hydrogen available at the cathode areas of the metal for the reduction of sulphate to sulphide. This is in agreement with the report Ma et al. [28] that corrosion of 99.99\% pure iron immersed in solution was inhibited by a protective layer of ferrous sulphide (FeS) under such conditions as less than $0.04 \mathrm{mmol} / \mathrm{dm}^{3}$ of hydrogen sulphide $\left(\mathrm{H}_{2} \mathrm{~S}\right)$ concentration, $\mathrm{pH}$ value of $3-5$ and an immersion time longer than two hours.

Similarly, the corrosion in the aerobic environment was also severe. Aerobic bacteria grow by assimilating $\mathrm{CO}_{2}$ using energy derived from the oxidation of sulphur to sulphite for their growth. A localized pitting corrosion results from the direct anaerobic bacteria reduction of the sulphate at the metal surface. This is possible because the biofilm formed by the bacteria creates an anaerobic condition. This is in agreement with the findings of Jin et al. [15] that pitting holes were observered on the surface of the steel in the soil extract solution with sulphate reducing bacteria, but not in the absence of sulphate reducing bacteria (SRB). They showed that the susceptibility of the steel to corrosion was more in the soil extract solution with SRB than that without SRB and the pitting corrosion readily occurred on the surface of the steel in the presence of SRB. This study also agrees with the findings of Faisal et al. [29] that the coupons immersed in the sulphate reducing consortium exhibited aggressive and deeper pitting. SRB inoculation inhibited the corrosion rate under aerobic condition at days 14 and 28 which are both $0.0004080 \mathrm{~mm} / \mathrm{yr}$. The whole surfaces of the corroded steel coupons were covered with homogeneous ferrous sulphide (FeS). When the entire coupon surface was covered with homogeneous ferrous sulphide, corrosion of carbon steel was inhibited due to passivation. This is in agreement with a study by Herrera et al. [30] which reported that when the entire coupon surface was covered with homogenous ferrous sulphide, corrosion of carbon steel was inhibited. The formation of a dirty green precipitate which is insoluble in excess sodium hydroxide confirms the presence of iron (II) oxide. It was observed that a general or uniform type of corrosion occurred on the specimen as the colour of the specimen gradually changed from grey eventually emerging dark in appearance with pale green patches in anaerobic environment while the specimen transformed from grey to reddish brown colour and eventually dark in aerobic environment. It was observed that the colour of the envi- 
ronments changed from colourless to brown, dark pale green and reddish brown in aerobic, anaerobic and the control environment respectively.

The observation under anaerobic condition indicated that hydrogen sulphide didn't accelerate corrosion of carbon steel. Corrosion acceleration by SRB activity such as the cathode depolarization was stopped at day 7 . This is in agreement with the findings of Mataqi et al. [31] using soil model where they discovered that upon the inoculation of SRB under aerobic conditions, little corrosion on the steel coupon were observed during the $14^{\text {th }}-28^{\text {th }}$ day of incubation period. They reported that sulphate concentration for the SRB inoculated in both anaerobic and aerobic conditions stopped decreasing at day 7 suggesting that the sulphate reducing activity of SRB was high until this day as it began to decrease afterwards. They equally indicated that the heterogeneous structure of the soil led to the formation of a heterogeneous biofilm with corrosion products on the carbon steel coupons. This is in agreement with this study that the heterogeneous biofilm that resulted in the uneven distribution of dissolved oxygen on the metal surface accelerated microbial corrosion. Dubiel et al. [32] reported that the corrosion of carbon steel in the culture inoculated with both sulphate oxidizing bacteria (SOB) and sulphate reducing bacteria (SRB) was accelerated compared to that in the culture inoculated with either SOB or SRB.

\section{Conclusion}

As steel undergoes corrosion in different environment, there tends to be an inverse relationship in the weight loss and the corrosion rate trends in the exposed steel. While weight loss tends to increase over time, corrosion rate tends to decrease simultaneously. The high carbon steel experienced a general corrosion in each environment. The corrosion rate of the high carbon steel was observed to be $0.0004595 \mathrm{~mm} / \mathrm{yr}$ in aerobic environment, $0.0005646 \mathrm{~mm} / \mathrm{yr}$ in anaerobic environment and $0.0004458 \mathrm{~mm} / \mathrm{yr}$ in distilled water (control) environment. These results were compared to those reported by Ovri et al. [22] in microbial corrosion of mild and medium carbon steel and Owate [26] in corrosion behaviour of mild and high carbon steels in various acidic media. In view of this, high carbon steels were found to be relatively more corrosion resistant than the mild and medium carbon steels and may be more suitable for application in the industries such as the petrochemical industry.

\section{Recommendations}

The effect of bacteria in the corrosion of high carbon steel has been evaluated and found to be partly responsible for failures of the material exposed in such environments which favours microbial growth.

\section{Conflicts of Interest}

The authors declare no conflicts of interest regarding the publication of this paper. 


\section{References}

[1] Shera, B.W., Power, I.M., Keech, P.C., Mitlin, S., Southam, G. and Shoesmith, D.W. (2011) Characterizing the Effect of Carbon Steel Exposure in Sulphide-Containing Solutions to Microbially Induced Corrosion. Corrosion Science, 53, 955-960. https://doi.org/10.1016/j.corsci.2010.11.027

[2] Borode, J.O. (1999) Effect of Carbon Content and Inhibitors in Corrosion of Steels. Nigerian Corrosion Journal, 2, 100-110.

[3] Koch, G.H., Brongers, M.P.H., Thompson, N.G., Virmanic, Y.P. and Payer, J.H. (2002) Corrosion Costs and Preventive Strategies in the United States. US Department of Transportation, Report No. FHWA-RD-01-156, Washington DC.

[4] Koch, G.H., Brongers, M.P.H., Thompson, N.G., Virmanic, Y.P. and Payer, J.H. (2001) Corrosion Costs and Preventive Strategies in the United States. FHWA-RD01-156.

[5] Kozlova, I., Koptera, Z., Zanina, V. and Purish, L. (2010) Microbial Corrosion as a Manifestation of Technogenesis in Biofilms Formed on Surface of Underground Structure. Materials Science, 46, 389-398. https://doi.org/10.1007/s11003-010-9302-4

[6] Javaherdashti, R. (2011) Impact of Sulfate-Reducing Bacteria on the Performance of Engineering Materials. Applied Microbiologyand Biotechnology, 9, 1507-1517. https://doi.org/10.1007/s00253-011-3455-4

[7] Zhang, C., Wen, F. and Cao, Y. (2011) Progress in Research of Corrosion and Protection by Sulphate-Reducing Bacteria. Proceedings of the Environmental Sciences, 10, 1177-1182.

[8] Von Wolzogen, K.C. and Van der Vlust, L.S. (1934) Graphitazation of Cast Iron as an Electrochemical Process in Anaerobic Soils. Water, 18, 147-165.

[9] King, R.A. and Miller, J.D. (1971) Corrosion by the Sulphate-Reducing Bacteria. Nature, 233, 491-492. https://doi.org/10.1038/233491a0

[10] McNeil, M.B. and Little, B.J. (1990) Technical Note: Mackinawrite Formation during Microbial Corrosion. Corrosion, 46, 599-600. https://doi.org/10.5006/1.3585154

[11] Benmoussa, A., Hadjel, M. and Trasnel, M. (2006) Corrosion Behavior of API 5LX-60 Pipeline Steel Exposed to Near Neutral pH Soil Simulating Solution. Materials and Corrosion, 57, 771-777. https://doi.org/10.1002/maco.200503964

[12] Urios, L., Marsal, F., Pellegrini, D. and Magot, M. (2013) Microbial Diversity at Iron-Clay Interfaces after 10 Years of Interaction Inside a Deep Argillite Geological Formation (Tournemire, France). Geomicrobiology Journal, 30, 442-453. https://doi.org/10.1080/01490451.2012.705227

[13] Almeida, M.A.N. and De Franca, F.P. (1998) Thermophilic and Mesophilic Bacteria in Biofilms Associated with Corrosion in a Heat Exchanger. World Journal of Microbial Biotechnology, 15, 439-442. https://doi.org/10.1023/A:1008963632593

[14] Rozanova, E.P., Dubinina, G.A., Lebedeva, E.V., Suntsova, L.A., Lipovskich, V.M. and Tsvetkov, N.N. (2003) Microorganisms in Heat Supply Systems and Internal Corrosion of Steel Pipelines. Microbiological, 72, 179-186.

[15] Jin, X.U., Cheng, S., Maocheng, Y. and Fuhui, W. (2012) Effects of Sulphate-Reducing Bacteria on Corrosion of Carbon Steel in the Crevice. International. Journal of Electrochemica Science, 7, 11297-11312.

[16] Gibson, G.R. (1990) Physiology and Ecology of the Sulphate-Reducing Bacteria. Journal of Applied Bacteriology, 69, 769-797. https://doi.org/10.1111/j.1365-2672.1990.tb01575.x 
[17] Wiener, M.S., Salas, B.V., Quintero-Nunez, M. and Ziater, R. (2006) Effect of Hydrogen Sulphide on Corrosion in Polluted Water. Corrosion Engineering Science and Technology, 41, 221-227. https://doi.org/10.1179/174327806X132204

[18] American Society for Testing and Materials (2009) Standard Practice for Preparing, Cleaning and Evaluating Corrosion Test Specimens. ASTM, Philadelphia, 17-23.

[19] National Association of Corrosion Engineers (2004) Field Monitoring of Bacteria Growth in Oil and Gas System. NACE, Houston.

[20] American Public Health Association (2005) Standard Methods for the Examination of Water and Wastewater. 19th Edition, APHA, Washington DC.

[21] Oparaodu, K.O. and Okpokwasili, G.C. (2014) Effects of Tetrakis (Hydroxymethyl) Phosphorium Sulphate Biocides on Metal Loss in Mild Steel Coupon Buried in a Water-Logged Soil. Journal of Applied and Environmental Microbiology, 2, 253-256.

[22] Ovri, J.E.O. (1992) Microbial Corrosion of Mild and Medium Carbon Steel. Nigerian Corrosion Association Seminar, 2, 121-124.

[23] Yuzwa, G.F. and Eng, P. (1991) Corrosion by Sulfate-Reducing Bacteria Presented at Alberta Public Works, Supplies and Services Property Management Operations Division. Water Treatment Co-Ordinators Meeting, Edmonton, 16 October 1991, 178-187.

[24] Carpen, L., Maukonen, J. and Salo, S. (2012) Accelerated Corrosion of Carbon Steel and Zinc in Oxygen-Free Groundwater. NACE International, 4, 1397-1399.

[25] Owate, I.O. (2008) Corrosion Behaviour of Mild and High Carbon Steels in Various Acidic Media. Scientific Research and Essays, 4, 120-125.

[26] Ovri, J.E.O. (2010) The Effect of Bacteria on the Corrosion of High Carbon Steel. Journal of Science and Engineering Technology, 1, 57-66.

[27] Wan, Y., Ding, L., Wang, X., Li, T., Sun, H. and Wang, Q. (2013) Corrosion Behaviour of Steel in Indoor Soil. International Journal of Electrochemical Science, 8, 12531-12542.

[28] Ma, H., Cheng, X., Li, S., Chen, Z., Quan, S., Zhao, L. and Niu, S. (2000) Effect of Sulphate-Reducing Bacteria on Corrosion of Carbon Steel. Corrosion Science, 42, 1669-1683. https://doi.org/10.1016/S0010-938X(00)00003-2

[29] Faisal, M.A., Charles, W., Shally, M.B., John, R.S., David, L.O., Brajendra, M. and Anthony, E.K. (2013) Influence of Sulphate-Reducing Bacteria Biofilm on Corrosion Behaviour of Low-Alloy, High-Strength Steel. International Biodeterioration and Biodegradation, 78, 34-42. https://doi.org/10.1016/j.ibiod.2012.10.014

[30] Herrera, L. and Videla, H. (2009) Role of Iron-Reducing Bacteria in Corrosion and Protection of Carbon Steel. International Biodeterioration, 63, 891-895. https://doi.org/10.1016/j.ibiod.2009.06.003

[31] Mataqi, K.Y. and Akbar, B.H. (2013) Sulfur Cycle of Microbial Corrosion on Carbon Steel in Soil Model. International Journal of Engineering Research and Applications, 3, 617-623.

[32] Dubiel, M., Hsu, C.H., Chien, C.C., Mansfeld, S. and Neroman, D.K. (2002) Microbial Respiration Can Protect Steel from Corrosion. Applied and Environmental Mircrobiology, 68, 1440-1445. https://doi.org/10.1128/AEM.68.3.1440-1445.2002 